\title{
Assessment of geospatial and hydrochemical interactions of groundwater quality, southwestern Nigeria
}

\author{
PraiseGod Chidozie Emenike (D) \\ Chidozie Charles Nnaji • Imokhai Theophilus Tenebe
}

Received: 17 January 2018 / Accepted: 12 June 2018 / Published online: 28 June 2018

(C) The Author(s) 2018

\begin{abstract}
Groundwater pollution resulting from anthropogenic activities and poor effluent management is on the rise in Nigeria. Hence, groundwater used for domestic purposes is questionable and therefore calls for scientific scrutiny. Investigation of hydrochemical interactions and quality of groundwater resource is essential in order to monitor and identify sources of water pollutants. As a result, groundwater samples were collected from 21 locations in Abeokuta South, Nigeria and analyzed for physicochemical parameters using standard methods. Results obtained were subjected to
\end{abstract}

Electronic supplementary material The online version of this article (https://doi.org/10.1007/s10661-018-6799-8) contains supplementary material, which is available to authorized users.

P. C. Emenike

Cranfield Water Science Institute, School of Water, Energy and Environment, Cranfield University, Bedfordshire MK43 0AL, UK

P. C. Emenike $(\bowtie) \cdot$ I. T. Tenebe

Department of Civil Engineering, Covenant University, Ota, Ogun State, Nigeria

e-mail: praisegod.emenike@ cranfield.ac.uk

P. C. Emenike

e-mail: praisegod.emenike@ covenantuniversity.edu.ng

I. T. Tenebe

e-mail: imokhai.tenebe@ covenantuniversity.edu.ng

C. C. Nnaji

Department of Civil Engineering, University of Nigeria, Nsukka, Enugu State, Nigeria

e-mail: chidozie.nnaji@unn.edu.ng hydrochemical and geospatial analyses. Water quality parameters investigated exhibited wide variations from location to location. $\mathrm{Fe}^{2+}, \mathrm{Mg}^{2+}, \mathrm{SO}_{4}{ }^{2-}, \mathrm{Cl}^{-}$, total hardness (TH), $\mathrm{Mn}, \mathrm{Na}^{+}, \mathrm{NO}_{3}{ }^{-}, \mathrm{SiO}_{2}$, and alkalinity exhibited the highest levels of variation with coefficients of variation of $131.3,92.8,83.9,76.7,65.9,64.3,57.6$, $57.2,57.0$, and 52.5, respectively. The average $\mathrm{pH}$ value was 6.76 with $71 \%$ of the water samples being slightly acidic. $\mathrm{Na}^{2+}, \mathrm{Mg}^{2+}, \mathrm{Fe}^{2+}$, and EC contents exhibited the most violation of drinking water standards with percent violations of 100, 52.4, 47.6, and 47.6\%, respectively. Parameters, such as $\mathrm{Mn}, \mathrm{Ca}^{2+}, \mathrm{NO}_{3}{ }^{-}$, and $\mathrm{CO}_{3}{ }^{2-}$, were within the WHO guideline values for drinking water in all the samples. The highest level of significant correlation was found to exist between $\mathrm{Na}^{+}$ and $\mathrm{Cl}^{-}(r=0.84, \alpha=0.01)$. Six principal components, which explained $83.5 \%$ of the variation in water quality, were extracted with the first $(34.1 \%)$ and second components $(15.7 \%)$ representing the influence of mineral dissolution and anthropogenic practices, respectively, on the hydrochemistry of the area. Four hydrochemical clusters were identified with distinctly partitioned water quality. Further analysis revealed that 38, 29, 24, and $9 \%$ of the samples were the $\mathrm{Na}-\mathrm{K}-\mathrm{HCO}_{3}$, Na-K-Cl$\mathrm{SO}_{4}, \mathrm{Ca}-\mathrm{Mg}-\mathrm{HCO}_{3}$, and $\mathrm{Ca}-\mathrm{Mg}-\mathrm{Cl}-\mathrm{SO}_{4}$ types, respectively. Anthropogenic activities are increasing threat to groundwater quality in the study location and therefore call for urgent attention. There is also a need for routine monitoring of groundwater in Abeokuta.

Keywords Groundwater - Abeokuta $\cdot$ Hydrochemical Pollution · Geospatial · Southwestern Nigeria 


\section{Introduction}

Unsafe drinking water is of growing concern and has been attracting global attention (WHO and UNICEF, 2014). Groundwater, a valuable resource, is faced with contamination and depletion due to the propagation of civilization and development near water resource (Emenike et al. 2017a, b; Gao et al. 2010; Karkra et al. 2016). Recently, a report published by WHO indicated that groundwater contamination is partly responsible for the death of 1.7 million children below the age of 5 years annually (WHO, 2017). This explains the fact that the socioeconomic status and health evaluations of many nations have been linked to the development of quality water resources (Akoto et al. 2017; Karikari and AnsaAsare 2006). The hydrochemistry of any groundwater is heavily dependent on water recharge, precipitation of minerals, soil interaction, dissolution of basement rocks, complementary action from other aquifers, and anthropogenic sources (Aly 2015; Das and Nag 2017; Pazand et al. 2012; Vázquez-Suñé et al. 2005). Various researchers have employed a wide range of analytical methods in order to understand the variability of water quality in groundwater aquifers (Arulbalaji and Gurugnanam, 2017; Barzegar et al. 2017; Edjah et al. 2017; Fijani et al. 2017; Rao et al. 2015; Chandrasekar et al. 2014; Selvakumar et al. 2014; Maiti et al. 2013; Wang, 2013; Chen et al. 2011; Giridharan et al. 2008). Most of these studies showed interesting results and also differentiated the effect of anthropogenic and natural sources on groundwater quality by interrelationships among ions present in water. Such studies have been of immense use in ascertaining the status of groundwater and their suitability for agricultural and domestic applications, as well as the level of treatment required before use (Assubaie 2015; Cao et al. 2014; Emenike et al. 2016; Golchin and Moghaddam 2016; Nazeer et al. 2014; Rasool et al. 2016; Tenebe et al. 2016; Zaidi et al. 2016).

The integration of geographical information system (GIS) and remote sensing (RS) tools have been adopted by other investigators to assess the resource potentials of groundwater reservoirs (Pinto et al. 2017; Ayele et al. 2014; Salari et al. 2014; Junge et al. 2010). GIS and RS tools have proven to be an effective tool to ascertain the accuracy of water quality and monitoring. Also, the combination of thematic layer maps, GIS, and RS tools has made it easier to understand the groundwater chemistry without depending on the lineament component alone. Furthermore, statistical tools such as hierarchical cluster analysis (HCA), principal component analysis (PCA), and cluster groupings (CG) have been accepted as explanatory techniques for analyzing the sources of groundwater and their pollution route (Selvakumar et al. 2014; Yidana, 2010).

In Abeokuta, Ogun State-Nigeria, groundwater sources are being exploited to meet the daily water demands for domestic and agricultural purposes (Odjegba et al. 2015; Adekunle et al. 2013). This situation is further exacerbated by anthropogenic activities resulting in the pollution of ground and surface water resources. The major industrial activities in Abeokuta that are responsible for water pollution included abattoirs, textile mills, sawmills, food processing industries, automobile workshops, as well as large volumes of solid waste generated daily and indiscriminately disposed of in the municipality. The health condition of the inhabitants is tied to environmental conditions, sanitation, and surrounding circumstances, but to maintain a healthy living, it is vital to ensure that the quality of water consumed complies with stipulated drinking water standards. Hence, consistent and proper monitoring is necessary.

In the area, less attention has been given to the hydrochemical analysis of the concentration of groundwater quality parameters. Several researchers have reported the general water characteristics in Abeokuta (Adekunle et al. 2013; Amori et al. 2013; Gbadebo, 2012; Taiwo, 2012). However, a holistic geochemical study integrating water quality parameters, GIS, and RS has not been reported in the literature. Therefore, it is important to understand the spatial variability of groundwater sources within the region. This study was aimed at assessing groundwater quality and hydrochemical interactions in the district and ascertaining the interrelationship of water quality parameters for potential pollution source identification, using RS, GIS, and statistical tools.

\section{Materials and methods}

Study area

The sampling sites for the study were in Abeokuta - the capital of Ogun state in Southwestern, Nigeria. Abeokuta is located near a cluster of rocky outcrops on the east bank of River Ogun. It lies between latitude 
$7.23^{\circ} \mathrm{N}$ and longitude $3.42^{\circ} \mathrm{E}$. The population of Abeokuta is estimated at 451,607 with an annual growth rate of 3.5\% (National Population Commission 2010; Ogbiye et al. 2018). The city is joined to Lagos by railway $(77 \mathrm{~km})$ or by water $(130 \mathrm{~km})$. Other neighboring towns that share common boundaries with Abeokuta include Ketou, Ilaro, Ibadan, Iseyin, and Shagamu.

\section{Sample collection}

Twenty-one groundwater samples collected from Abeokuta South (Fig. 1) during September 2016 from taps located in 21 different locations (R1-R21) were analyzed in this study. The taps used in this study get their supply from boreholes. Each tap was allowed to run for 10-15 min, and three samples were collected to obtain the mean value of each physicochemical parameter.

Before obtaining the samples, polyethylene containers with screw cocks were rinsed with distilled water having $20 \% \mathrm{HNO}_{3}$. The polyethylene bottles were further rinsed with distilled water and air-dried before taking it to the collection site. On the collection site, the pre-washed polyethylene containers were rinsed three times with the tap water before representative samples were obtained. The representative samples were labeled correctly and transported to a laboratory in an ice box and later transferred to a refrigerator calibrated to $4{ }^{\circ} \mathrm{C}$.

Field measurements of water quality parameters include hydrogen ion concentration $(\mathrm{pH})$, total dissolved solids (TDS), temperature (temp.), electrical conductivity (EC), and alkalinity (Alka.). The field measurements were performed using a multiparameter Hanna edge HI2030 EC/TDS/salinity meter and Hanna HI98130 probe. Other water parameters, such as dissolved silica $\left(\mathrm{SiO}_{2}\right)$, major anions (carbonates $\left(\mathrm{CO}_{3}{ }^{2-}\right)$, bicarbonates $\left(\mathrm{HCO}_{3}{ }^{-}\right)$, chloride $\left(\mathrm{Cl}^{-}\right)$, nitrates $\left(\mathrm{NO}_{3}{ }^{-}\right)$, and sulfates $\left(\mathrm{SO}_{4}{ }^{2-}\right)$ ), and major cations (calcium $\left(\mathrm{Ca}^{2+}\right)$, sodium $\left(\mathrm{Na}^{+}\right)$, magnesium $\left(\mathrm{Mg}^{2+}\right)$, and potassium $\left(\mathrm{K}^{+}\right)$) were measured using standard procedures laid out by the American Public Health Association (APHA, 2005). The concentration of iron $\left(\mathrm{Fe}^{2+}\right)$ and manganese $(\mathrm{Mn})$ was measured under a standard operating condition with a flame atomic absorption spectrophotometer (Perkin Elmer PinAAcle500), and the fluoride ion $\left(\mathrm{F}^{-}\right)$was measured using a calibrated potentiometric ionselective electrode (HI5315 reference electrode attached to Hanna HI98191 professional water-resistant portable pH/ISE/ORP meter).

Data analysis

Laboratory results were subjected to descriptive statistical analyses. The degree of violation of each water quality parameter was estimated by considering the number of times it exceeded the WHO water quality guidelines. Correlation between parameters was also performed using Pearson's pairwise correlation at 0.05 and 0.01 levels of significance. A geospatial map of each physicochemical parameter was produced using QGIS 2.18.11. PCA was used to reduce the
Fig. 1 Map of study area showing sampling points

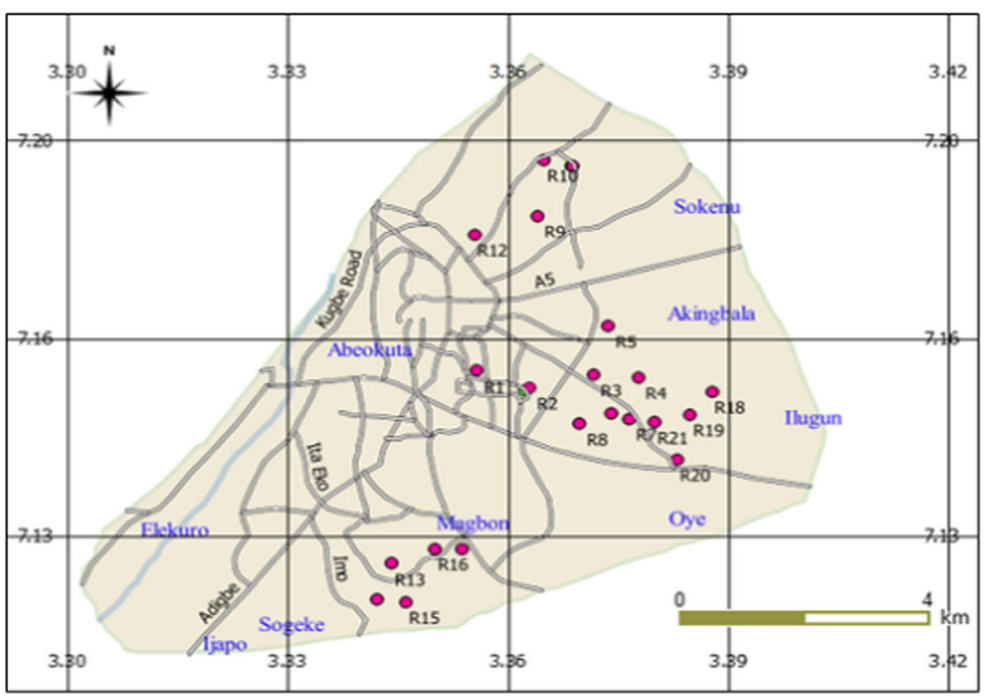




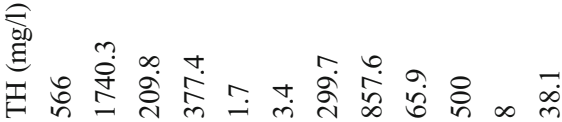

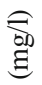

兽

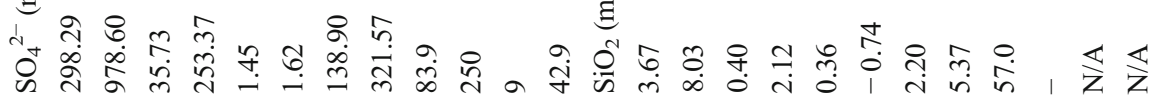

$\widehat{\overparen{\text { ad }}}$

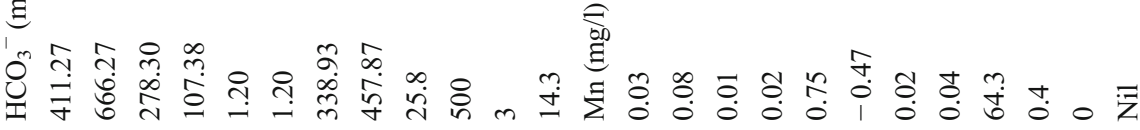

突

๘્0

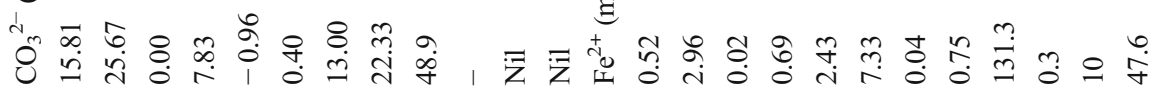

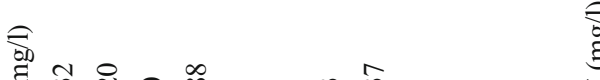

है

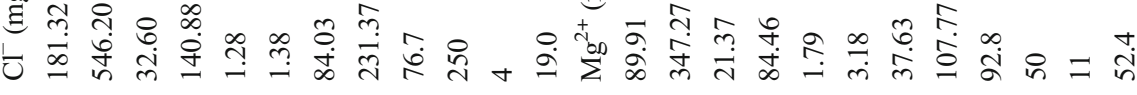

है

ڤ્ळ

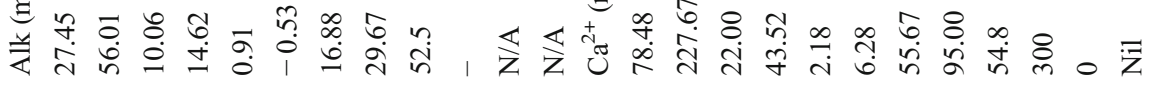

రิ

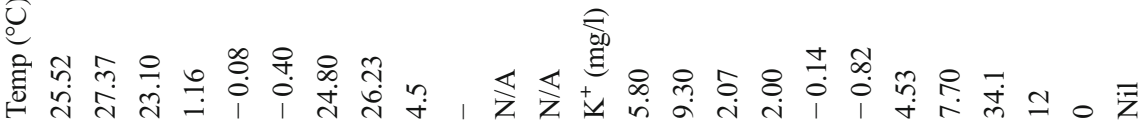

हิ

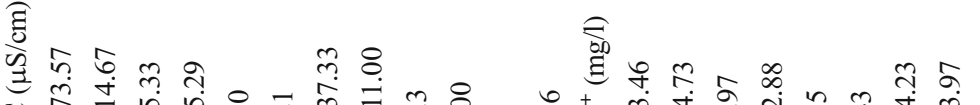

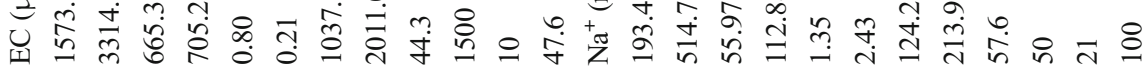

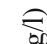

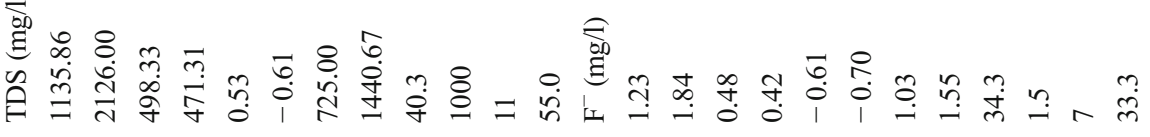

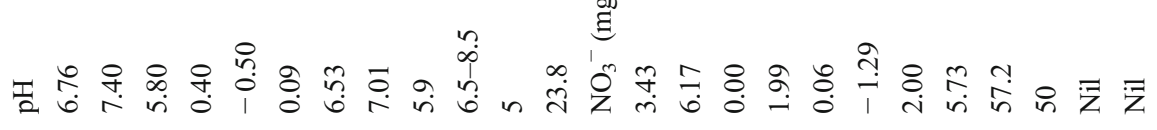

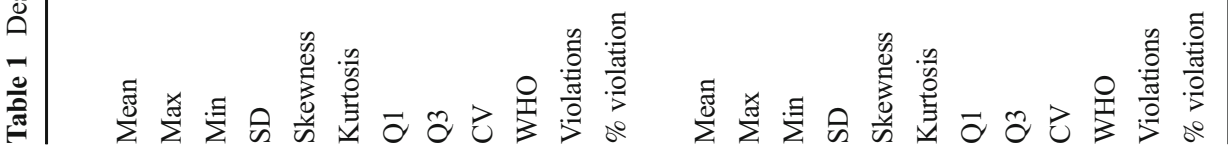


dimensionality of the parameters (18 of them) for ease of interpretation. The standardized principal component analysis (SPCA) method was applied to the 18 water quality parameters using the Statistical Package for Social Sciences (SPSS). The extracted principal components were subject to Varimax rotation in order to better distinguish the factor loadings on the parameters. Next, HCA was applied to the parameters as well as the sampling points. CG of parameters served as a confirmation for the results of the PCA. CG of sampling points were used for spatial delineation of water quality. HCA is the most widely used method for classifying a group of data into similar subgroups (Khound and Bhattacharyya 2016). In this paper, Ward's method of linkage and squared Euclidean distance were employed. Finally, a hydrochemical classification of the water samples was attempted by generating Piper trilinear plots using Piperplot-QW.

\section{Results and discussion}

Physicochemical parameters of groundwater

Table S1 (in the Supplementary material) is the result of the water quality analysis obtained from the laboratory. In order to facilitate an in-depth interpretation of these results, the descriptive statistics of these parameters have been provided in Table 1. Table S1 shows that despite the geographical proximity of the sampling points, the water quality parameters exhibited wide variations from location to location. $\mathrm{Fe}^{2+}, \mathrm{Mg}^{2+}, \mathrm{SO}_{4}{ }^{2-}$, $\mathrm{Cl}^{-}$, total hardness (TH), Mn, $\mathrm{Na}^{+}, \mathrm{SiO}_{2}$, and alkalinity exhibited the highest levels of variation with coefficients of variation of 131.3, 92.8, 83.9, 76.7, 65.9, 64.3, 57.6, $57.2,57.0$, and 52.5 respectively. These wide variations may be due to the variabilities in the solubility of aquifer materials, recharge zones, and anthropogenic activities at the sampling points. Temperature and $\mathrm{pH}$ had the least degree of variability of 4.5 and 5.9, respectively. While the temperature of water is not of serious concern in terms of potable water quality, $\mathrm{pH}$ is a significant water quality parameter. $\mathrm{pH}$ indicates the strength of the water to react with acidic or alkaline materials in water (Islam et al. 2017) and is a controlling factor that determines the types of ion present in water. Hence, water with low (acidic) $\mathrm{pH}$ is more likely to dissolve aquifer materials. The average $\mathrm{pH}$ value was 6.76 with a skewness of 0.5. This implies that a higher proportion of the water samples fell in the acid $\mathrm{pH}$ range. In fact, $71 \%$ of the water samples were slightly acidic. Generally, low water $\mathrm{pH}$ and high $\mathrm{Fe}^{2+}$ content are characteristics of the weathered basement complex rocks of southwestern Nigeria (Oke and Tijani 2012; Ufoegbune et al. 2009). Furthermore, a significant positive correlation exists between $\mathrm{pH}$ and $\mathrm{Fe}^{2+}$, thus indicating a possible influence of industrial activities on water quality. This result is supported by the findings of Romshoo et al. (2017), where he reported high variability of $\mathrm{Fe}^{2+}$ (mean $\mathrm{pH}$ 7.45 ) in the groundwater in Jammu Siwaliks, India due to iron release from industries.

The degree of non-compliance of water quality parameters with WHO drinking water quality standards was computed as a percentage of the total number of times a parameter exceeded stipulated standards. It was found that $\mathrm{Na}^{2+}, \mathrm{Mg}^{2+}, \mathrm{Fe}^{2+}$, and $\mathrm{EC}$ exhibited the most
Table 2 Suitability of water samples for drinking

\begin{tabular}{llll}
\hline Water class & & $\begin{array}{l}\text { No. of sample } \\
\text { in each class }\end{array}$ & $\begin{array}{l}\% \text { of sample } \\
\text { in each class }\end{array}$ \\
\hline $\begin{array}{l}\text { TDS(mg/l) } \\
<500\end{array}$ & Desirable for drinking & 1 & 4.76 \\
$500-1000$ & Permissible for drinking & 9 & 42.86 \\
$1000-3000$ & Useful for irrigation & 11 & 52.38 \\
$>3000$ & Unfit for drinking & 0 & 0 \\
$\mathrm{TH}\left(\mathrm{mgCaCO}_{3} / \mathrm{l}\right)$ & Soft & 0 & 0 \\
$<60$ & Moderately hard & 0 & 0 \\
$60-120$ & hard & 0 & 0 \\
$121-180$ & Very hard & 21 & 100 \\
$>180$ & & & 0 \\
\hline
\end{tabular}




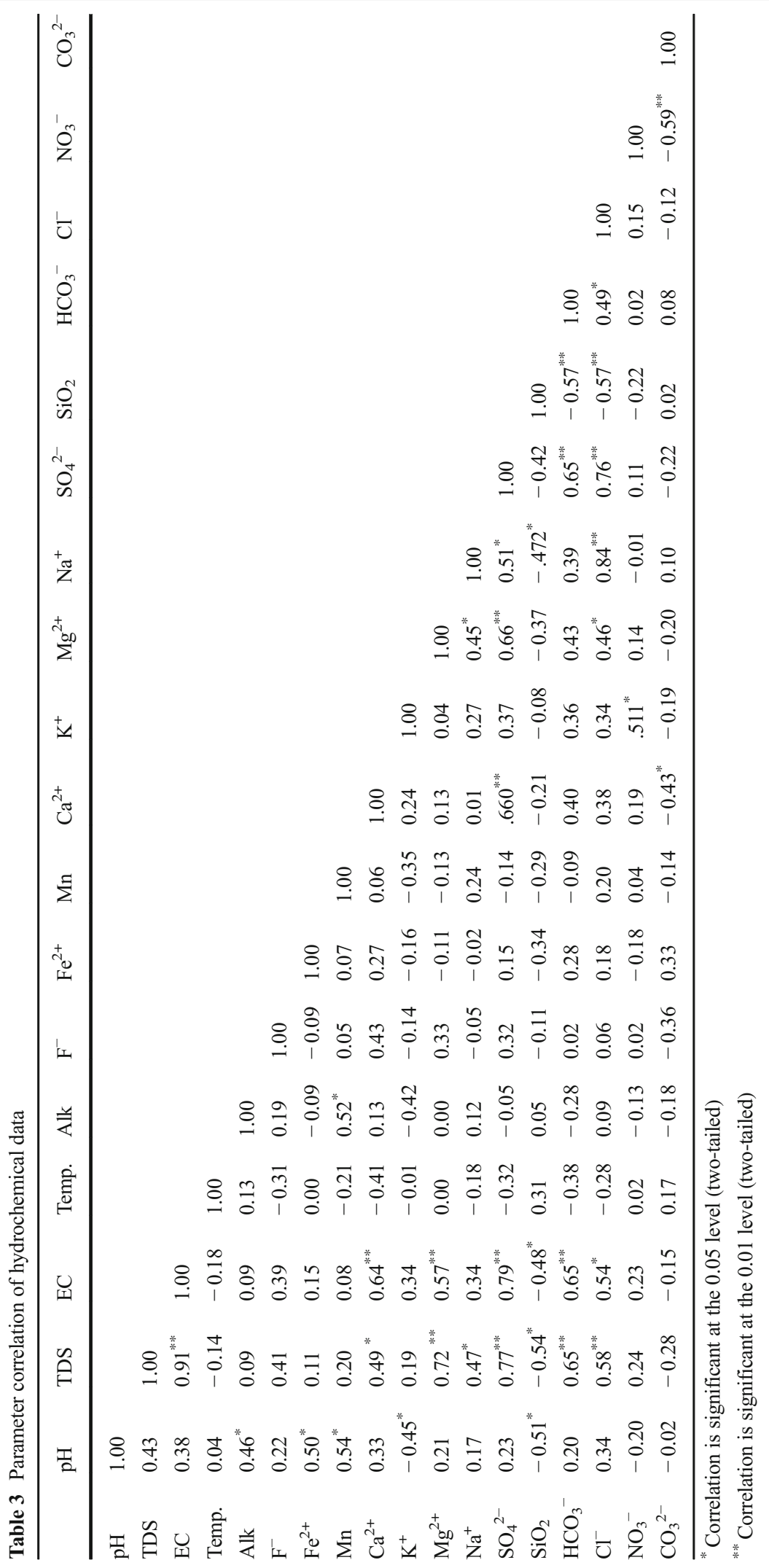


violation of drinking water standards with percent violations of 100, 52.4, 47.6, and 47.6\%, respectively. High levels of $\mathrm{Na}^{+}$could be as a result of erosion of salt deposits and sodium-bearing rocks, groundwater pollution by sewage, irrigation, and precipitation leaching of soils high in sodium. Sodium concentration greater than $200 \mathrm{mg} / \mathrm{L}$ was observed in the samples collected from region R5, R1, R8, R2, R3, and R11 in their increasing order, respectively (Table S1). But when compared with Al-Qassim in central Saudi Arabia (El Alfy et al. 2018), Southern Tiruchirappalli District in India (Selvakumar et al. 2017), and Torbat-Zaveh Plain in Iran, the sodium content obtained in this study was lesser (Nematollahi et al. 2016). While $\mathrm{Na}^{+}$is not of serious health concern with respect to drinking water, its presence in high concentration can lead to the deterioration of soil structure and reduced crop yield if the water is used for irrigation (Islam et al. 2017). The high levels of $\mathrm{Fe}^{2+}$ in the groundwater samples is probably due to the low water $\mathrm{pH}$ resulting in the corrosion of water delivery pipes and leaching of $\mathrm{Fe}^{+}$from the weathered basement complex. Although $\mathrm{Fe}^{2+}$ is an essential element in humans and is of little health concern, its presence in water constitutes a nuisance (Nag and Das 2017). High levels of $\mathrm{Fe}^{2+}$ in drinking water can impart taste, stimulate bacterial growth, and cause stains on clothes, fittings, and utensils. Parameters, such as $\mathrm{Mn}, \mathrm{Ca}^{2+}, \mathrm{NO}_{3}{ }^{-}$, and $\mathrm{CO}_{3}{ }^{2-}$, were always within the WHO guideline values for drinking water. Khound and Bhattacharyya
(2016) observed that the solubility of Mn is high in low $\mathrm{pH}$, but that does not seem to be the case in this study. They further observed that $\mathrm{Fe}^{2+}$ generally coexists with $\mathrm{Mn}$ in water, but the concentration of $\mathrm{Fe}^{2+}$ is always higher than Mn due to its crustal abundance. In line with this, it was observed that $\mathrm{Fe}^{2+}$ was higher than $\mathrm{Mn}$ in $86 \%$ of the samples analyzed. TDS and EC exhibited 55 and $47.6 \%$ violations of WHO guideline values (Table 1). TDS can be used as a firsthand assessment of the potability of water (Sharma et al. 2016). TDS level in water is dependent on the chemical nature of the water as well as the solubility of the aquifer materials through which the water is flowing. Aghazadeh et al. (2016) noted that high TDS and EC could be attributed to ion exchange, evaporation, sediment dissolution, and rainwater infiltration. Heavy use of agro-chemicals can also contribute to high levels of TDS in groundwater. Sharma et al. (2016) noted that high levels of groundwater TDS could result from the contribution of dissolved salts from the unsaturated zone. The high levels of TDS in the groundwater samples investigated should be a source of great concern. It has been established that high levels of TDS can lead to gastrointestinal irritations and laxative effects (Selvakumar et al. 2014).

The classification provided by Davis and De Wiest (1966) was further used to assess the potability of the water samples. Table 2 shows that only $47.62 \%$ of the water samples is fit for drinking, while the remaining $52.38 \%$ will be useful for irrigation. Regarding
Fig. 2 Scree plot of principal components

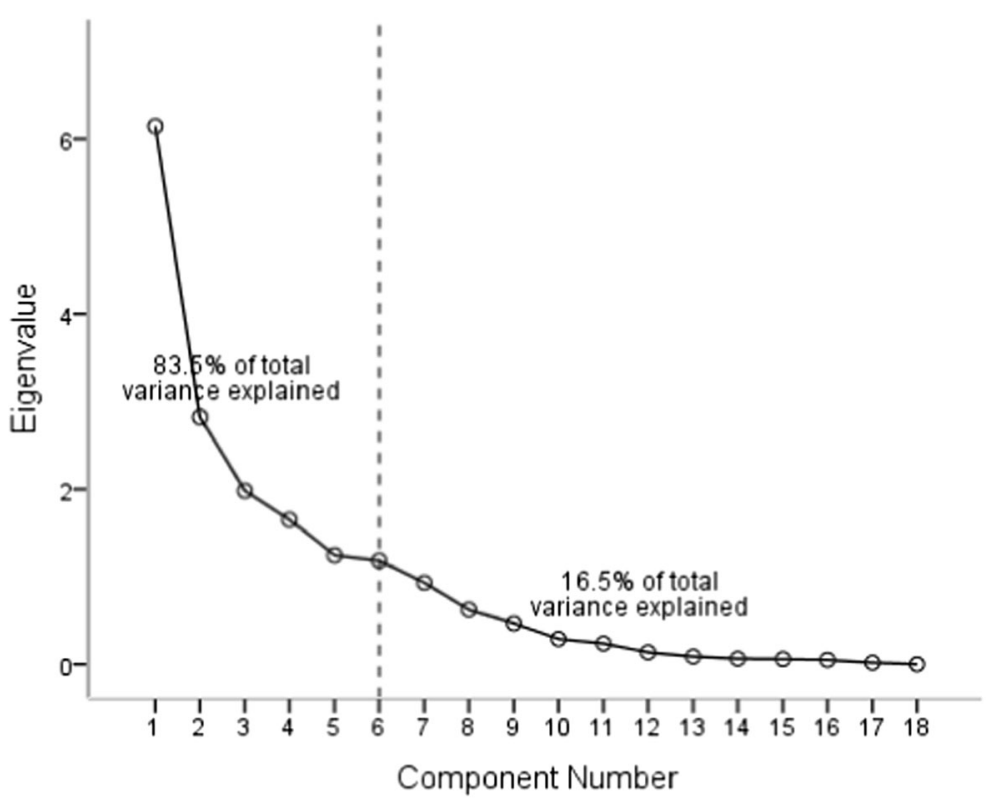


Table 4 Principal components of groundwater parameters

\begin{tabular}{|c|c|c|c|c|c|c|}
\hline \multirow[t]{2}{*}{ Parameter } & \multicolumn{6}{|l|}{ Component } \\
\hline & PC1 $(34.1 \%)$ & PC $2(15.68 \%)$ & PC $3(11.01 \%)$ & PC $4(9.16 \%)$ & PC $5(6.92 \%)$ & PC 6 (6.58) \\
\hline $\mathrm{pH}$ & 0.32 & 0.12 & 0.67 & -0.13 & 0.57 & -0.03 \\
\hline TDS & 0.88 & 0.30 & 0.10 & 0.15 & 0.18 & 0.04 \\
\hline $\mathrm{EC}$ & 0.77 & 0.16 & 0.05 & 0.30 & 0.30 & 0.20 \\
\hline Temp & -0.03 & -0.28 & 0.08 & 0.09 & 0.01 & -0.91 \\
\hline Alkalinity & 0.06 & 0.00 & 0.85 & 0.03 & -0.11 & -0.04 \\
\hline $\mathrm{F}^{-}$ & 0.54 & -0.32 & 0.30 & 0.03 & -0.17 & 0.47 \\
\hline $\mathrm{Fe}^{2+}$ & 0.03 & 0.00 & -0.01 & -0.21 & 0.89 & -0.01 \\
\hline $\mathrm{Mn}$ & -0.14 & 0.47 & 0.75 & -0.02 & 0.15 & 0.10 \\
\hline $\mathrm{Ca}^{2+}$ & 0.48 & -0.12 & 0.05 & 0.33 & 0.38 & 0.57 \\
\hline $\mathrm{K}^{+}$ & 0.10 & 0.25 & -0.63 & 0.60 & -0.03 & 0.04 \\
\hline $\mathrm{Mg}^{2+}$ & 0.87 & 0.23 & 0.00 & 0.00 & -0.19 & -0.16 \\
\hline $\mathrm{Na}^{+}$ & 0.29 & 0.90 & 0.06 & -0.03 & -0.11 & 0.01 \\
\hline $\mathrm{SO}_{4}^{2-}$ & 0.78 & 0.29 & -0.15 & 0.18 & 0.15 & 0.33 \\
\hline $\mathrm{SiO}_{2}$ & -0.25 & -0.54 & -0.17 & -0.22 & -0.48 & -0.17 \\
\hline $\mathrm{HCO}_{3}{ }^{-}$ & 0.51 & 0.39 & -0.36 & -0.01 & 0.41 & 0.27 \\
\hline $\mathrm{Cl}^{-}$ & 0.41 & 0.75 & 0.06 & 0.20 & 0.15 & 0.19 \\
\hline $\mathrm{NO}_{3}^{-}$ & 0.09 & 0.13 & -0.15 & 0.88 & -0.03 & -0.13 \\
\hline $\mathrm{CO}_{3}{ }^{2-}$ & -0.31 & 0.11 & -0.20 & -0.71 & 0.30 & -0.22 \\
\hline
\end{tabular}

hardness, all the 21 samples were categorized as very hard with a TH of greater than $180 \mathrm{MgCaCO}_{3} / 1$. Hardness results from the presence of sulfate, chloride, and bicarbonates of calcium and magnesium. TH impairs the lather-forming ability of water thereby leading to wastage of water and detergent during laundry. Hard water is generally of little health concern, but can cause serious problems in industrial settings where it can lead to the breakdown of boilers, cooling towers, and other equipment as a result of scum formation (Ramya et al. 2015).

Correlation of physicochemical parameters

Pearson's correlation coefficients were computed for each pair of the parameters as shown in Table 3. A significant correlation was found to exist between
Fig. $3 \mathrm{Na}^{+} / \mathrm{Cl}^{-}$ratio plot of groundwater samples

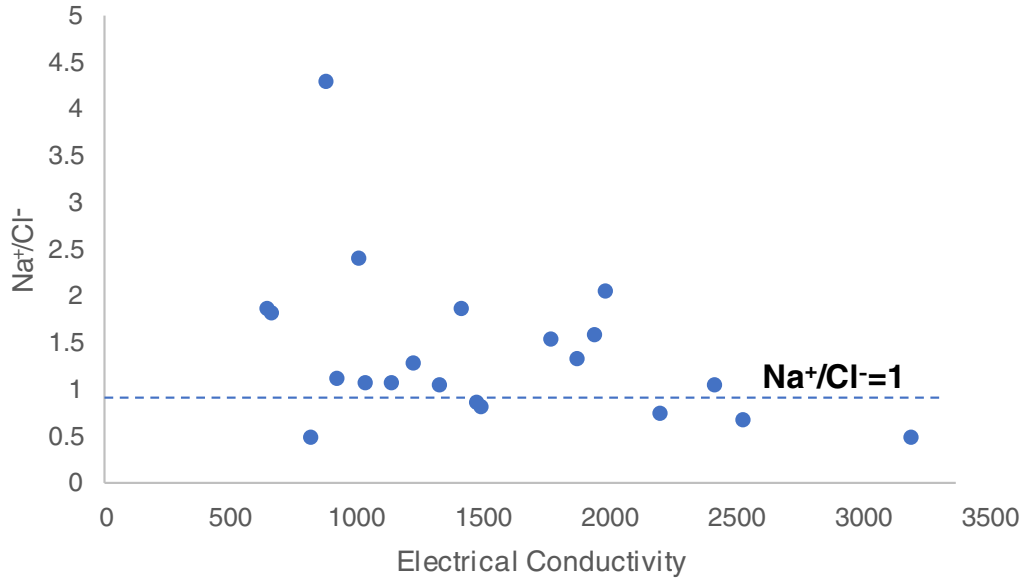



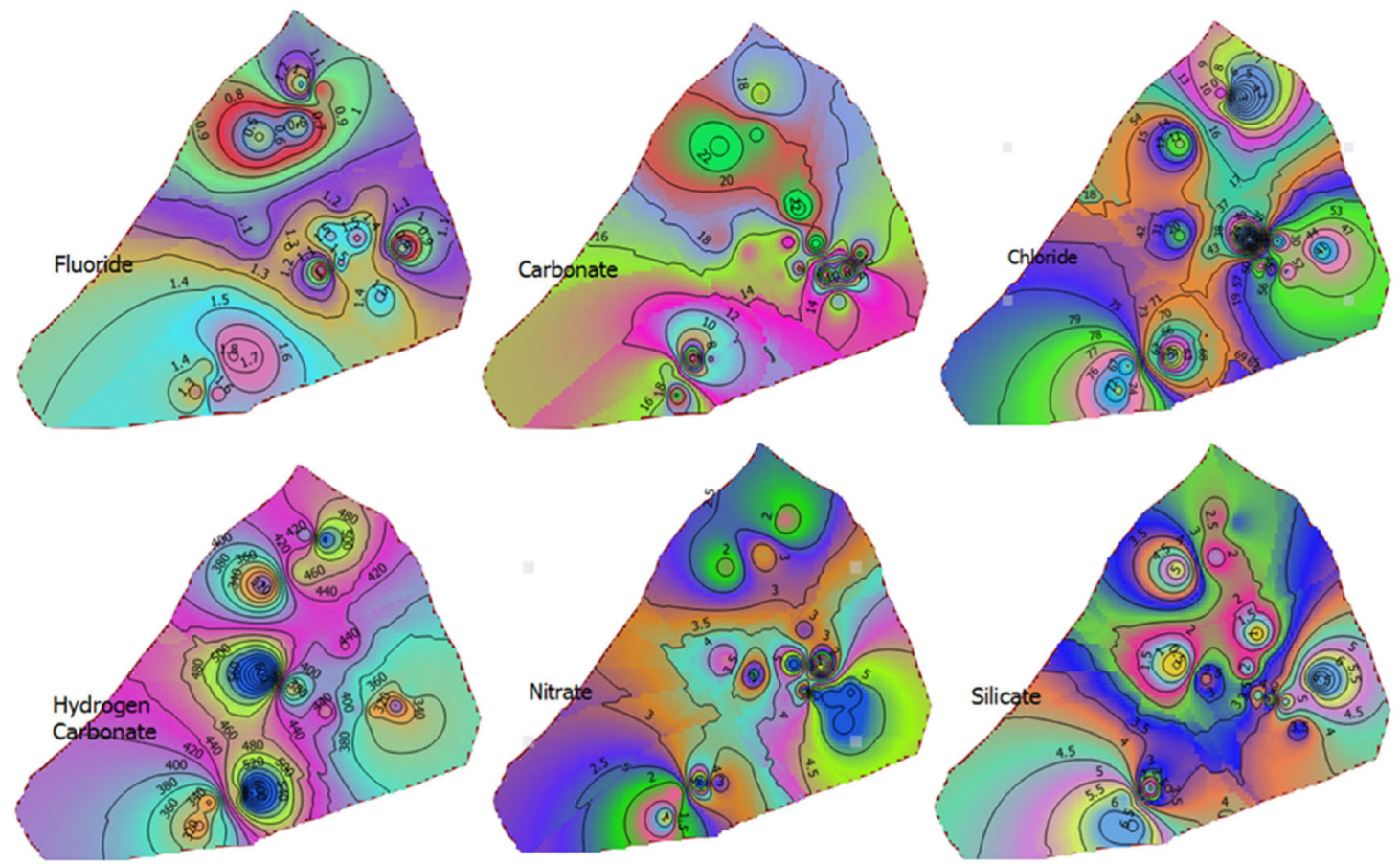

(a)
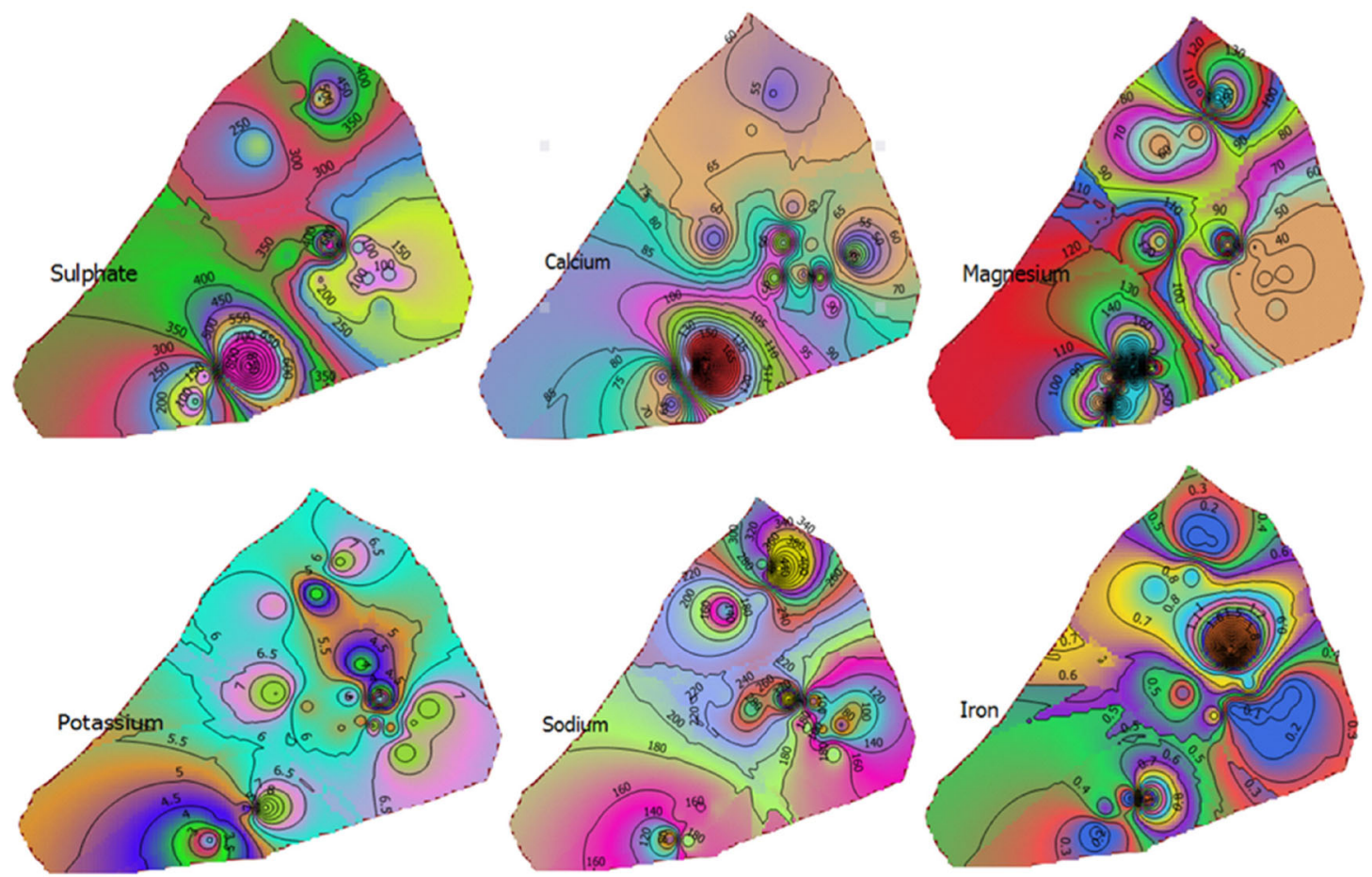

(b)

Fig. 4 a Geospatial distribution of $\mathrm{SiO}_{2}, \mathrm{CO}_{3}{ }^{2-}, \mathrm{HCO}_{3}^{-}, \mathrm{Cl}^{-}, \mathrm{NO}_{3}^{-}$, and $\mathrm{F}^{-}$. b Geospatial distribution of $\mathrm{SO}_{4}{ }^{2-}, \mathrm{Ca}^{2+}, \mathrm{Na}^{+}, \mathrm{Mg}^{2+}, \mathrm{K}^{+}$, and $\mathrm{Fe}^{2+}$ 
Fig. 5 Hierarchical cluster groupings based on water quality parameters

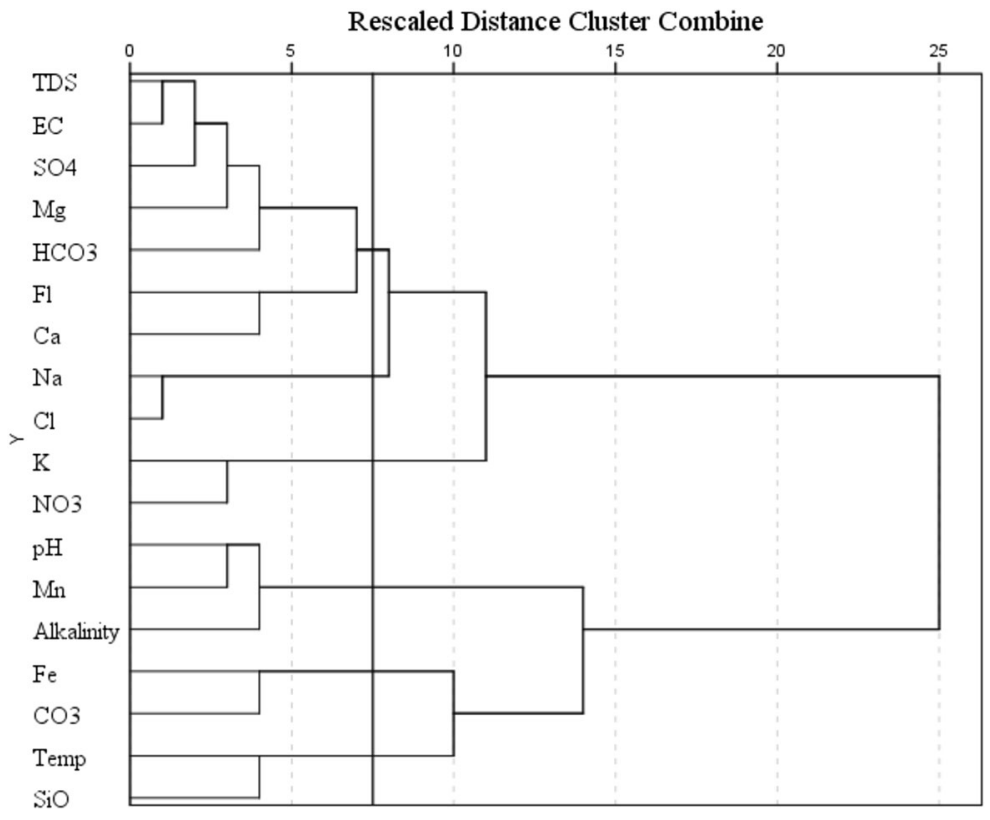

$\mathrm{Na}^{+}$and $\mathrm{Cl}^{-}(r=0.84, \alpha=0.01)$. Significant and positive correlation was also obtained between TDS and cations, such as $\mathrm{Mg}^{2+}(r=0.72, \alpha=0.01), \mathrm{Ca}^{2+}(r=$ $0.49, \alpha=0.05)$, and $\mathrm{Na}^{+}(r=0.57, \alpha=0.05)$, and anions, such as $\mathrm{SO}_{4}{ }^{2-}(r=0.77, \alpha=0.01), \mathrm{HCO}_{3}{ }^{-}(r=$ $0.65, \alpha=0.01), \mathrm{Cl}^{-}(r=0.58, \alpha=0.01)$, and $\mathrm{SiO}_{2}(r=$ $-0.54, \alpha=0.01)$. This suggests that hardness-causing ions contributed a high proportion of the TDS. Further analysis showed that a significant positive correlation of $0.84(\alpha=0.01)$ existed between TDS and TH. Nag and Das (2017) observed that impurities in limestone, such as $\mathrm{SO}_{4}{ }^{2-}, \mathrm{Cl}^{-}$, and $\mathrm{SiO}_{2}$, become exposed to the solvent action of water, as carbonates are dissolved so that they also pass into solution. This partly explains the high correlation between TDS and TH as well as $\mathrm{Ca}^{2+}$ and $\mathrm{SO}_{4}{ }^{2-}(r=0.66, \alpha=0.01)$ and $\mathrm{Cl}^{-}(r=0.46$, $\alpha=0.05)$. The high correlation coefficient between $\mathrm{Na}^{+}$and $\mathrm{Cl}^{-}$in groundwater samples is commonly reported in the literature and can be attributed to the dissolution of anhydrite, gypsum, and halite (Islam et al. 2017; Sreedhar et al. 2016; Li et al. 2013; Giridharan et al. 2009). The same also goes for the high correlation between $\mathrm{Ca}^{2+}$ and $\mathrm{SO}_{4}{ }^{2-}$. Potassium $\left(\mathrm{K}^{+}\right)$ and $\mathrm{NO}_{3}{ }^{-}$were not significantly correlated to any other ions apart from each other $(r=0.511, \alpha=0.05)$. This suggests that both ions enter groundwater from the same source and via the same route which is most likely fertilizer application for agricultural purposes. Fluoride and manganese were not correlated with any ion.
Principal component analysis of groundwater quality parameters

PCA aids the interpretation of complex multidimensional data matrices for a better understanding of water quality (Emenike et al. 2017a, b; Sreedhar et al. 2016). Six principal components whose Eigenvalues were greater than one were extracted from the 18 parameters. These six principal components accounting for $78 \%$ reduction in dimensionality explained $83.5 \%$ of the total variance (Fig. 2). The first principal component (PC1) explained $34.1 \%$ of the total variance and has a high positive loading on TDS (0.88), $\mathrm{Mg}^{2+}(0.87), \mathrm{SO}_{4}{ }^{2-}(0.78), \mathrm{EC}(0.77), \mathrm{F}^{-}$ $(0.54)$, and $\mathrm{HCO}_{3}^{-}(0.51)$ as shown in Table 4. Obviously, PC1 represents the influence of mineral dissolution from geological formations on the hydrochemistry of groundwater. This implies that the quality of water in the study area is greatly dependent on the aquifer material. Oke and Tijani (2012) observed that weathering effect aided by abundant rainfall experienced in the area leads to continuous leaching of minerals into groundwater. Hence, it follows that mineral dissolution has more effect on the hydrochemistry of Abeokuta South than anthropogenic activities.

The second principal component (PC2) explained $15.7 \%$ of the total variance with high loadings on $\mathrm{Na}^{+}$ and $\mathrm{Cl}^{-}$. Both $\mathrm{Na}^{+}$and $\mathrm{Cl}^{-}$are widely distributed in nature as $\mathrm{NaCl}$. These ions can enter water by weathering of rocks, agricultural chemicals, septic tank 
Table 5 Hydrochemical characteristics of cluster groupings

\begin{tabular}{|c|c|c|c|c|c|}
\hline Parameter & Cluster 1 & Cluster 2 & Cluster 3 & Cluster 4 & WHO limit \\
\hline $\mathrm{pH}$ & 6.8 & 6.3 & 7.0 & 7.1 & $6.5-8.0$ \\
\hline TDS (mg/l) & 875.3 & 834.2 & 1286.9 & 1833.3 & 1000 \\
\hline $\mathrm{EC}(\mu \mathrm{S} / \mathrm{cm})$ & 1154.4 & 1235.6 & 1638.5 & 2678.8 & 1500 \\
\hline Temp $\left({ }^{\circ} \mathrm{C}\right)$ & 25.6 & 25.8 & 25.4 & 25.3 & - \\
\hline Alka (mg/l) & 34.3 & 18.2 & 22.8 & 38.0 & - \\
\hline $\mathrm{F}^{-}(\mathrm{mg} / \mathrm{l})$ & 1.5 & 1.1 & 0.8 & 1.7 & 1.5 \\
\hline $\mathrm{Fe}(\mathrm{mg} / \mathrm{l})$ & 0.3 & 0.2 & 1.0 & 0.6 & 0.3 \\
\hline Mn (mg/l) & 0.03 & 0.02 & 0.0 & 0.0 & 0.4 \\
\hline $\mathrm{Ca}^{2+}(\mathrm{mg} / \mathrm{l})$ & 60.0 & 62.3 & 66.8 & 132.2 & 300 \\
\hline $\mathrm{K}^{+}(\mathrm{mg} / \mathrm{l})$ & 3.6 & 7.3 & 5.8 & 6.5 & 12 \\
\hline $\mathrm{Mg}^{2+}(\mathrm{mg} / \mathrm{l})$ & 69.5 & 46.3 & 108.6 & 174.6 & 50 \\
\hline $\mathrm{Na}^{+}(\mathrm{mg} / \mathrm{l})$ & 128.2 & 159.8 & 269.9 & 257.2 & 50 \\
\hline $\mathrm{SO}_{4}^{2-}(\mathrm{mg} / \mathrm{l})$ & 128.9 & 202.4 & 316.5 & 687.1 & 250 \\
\hline $\mathrm{SiO}_{2}(\mathrm{mg} / \mathrm{l})$ & 5.4 & 4.5 & 1.7 & 2.2 & - \\
\hline $\mathrm{HCO}_{3}{ }^{-}(\mathrm{mg} / \mathrm{l})$ & 352.3 & 337.5 & 516.6 & 485.8 & 500 \\
\hline $\mathrm{Cl}^{-}(\mathrm{mg} / \mathrm{l})$ & 56.6 & 133.6 & 250.3 & 349.1 & 250 \\
\hline $\mathrm{NO}_{3}^{-}(\mathrm{mg} / \mathrm{l})$ & 1.2 & 4.5 & 3.3 & 4.1 & 50 \\
\hline $\mathrm{CO}_{3}{ }^{2-}(\mathrm{mg} / \mathrm{l})$ & 20.1 & 15.4 & 19.8 & 10.1 & - \\
\hline TH (mg/l) & 435.9 & 345.9 & 615.9 & 1048.6 & 500 \\
\hline$\%$ violation & 26.7 & 13.3 & 57.1 & 64.3 & - \\
\hline
\end{tabular}

effluent, animal waste, municipal landfill leachate, seawater, basin brines, road deicers, and irrigation discharge (Bora and Goswami 2016; Panno et al. 2006). Etteieb et al. (2015) also observed that high levels of $\mathrm{Na}^{+}$and $\mathrm{Cl}^{-}$in water may be attributed to increase in industrial water pollution probably from uncontrolled discharge of industrial effluent. The relationship between $\mathrm{Na}^{+}$and $\mathrm{Cl}^{-}$is often used to identify the mechanism of acquiring salinity and to quantify atmospheric contribution (Tiwari and Singh 2014). The average $\mathrm{Na}^{+}$/ $\mathrm{Cl}^{-}$ratio of 1.4 (Fig. 3) suggests limited contribution from the atmospheric precipitation and reveals that the high levels these ions are most likely from weathering of rocks and anthropogenic sources. Only six of the samples have $\mathrm{Na}^{+} / \mathrm{Cl}^{-}<1.0$, indicating limited role of ion exchange from $\mathrm{Ca}^{2+}$ and $\mathrm{Mg}^{2+}$ in clays. With respect to the study area, $\mathrm{Na}^{+}$and $\mathrm{Cl}^{-}$might have been introduced into groundwater from municipal solid waste leachate, septic tank effluent, industrial effluent, and animal and agricultural waste. Hence, PC2 represents the influence of poor waste management on groundwater chemistry. PC3 has a high positive loading on alkalinity and $\mathrm{pH}$ and a high negative loading on $\mathrm{K}^{+}$. While it is not clear what this principal component represents, it seems to point to the influence of the natural environment (soil and air) on the chemistry of groundwater. PC4 has a high loading on $\mathrm{K}^{+}$and $\mathrm{NO}_{3}{ }^{-}$with an explained variance of $9.16 \%$. This component obviously represents the impact of agricultural practices on groundwater quality. Common sources of $\mathrm{NO}_{3}{ }^{-}$are fertilizers,

Table 6 Causes and water quality status in Abeokuta environment

\begin{tabular}{llll}
\hline Location & Pollution sources & Pollutants identified & References \\
\hline Kotopo and Ajebo & Mechanic site & Fe, nitrates (high) & Olusheyi (2017) \\
Lafenwa & Abattoir, sawmill, Locust beans processing factories & Chloride, nitrate, phosphate & Ojekunle et al. (2016) \\
Alabata Road & Poultry and dumpsite waste & pH and EC (high) & Taiwo et al. (2013) \\
\hline
\end{tabular}


Fig. 6 Composite geospatial map of water quality in Abeokuta South

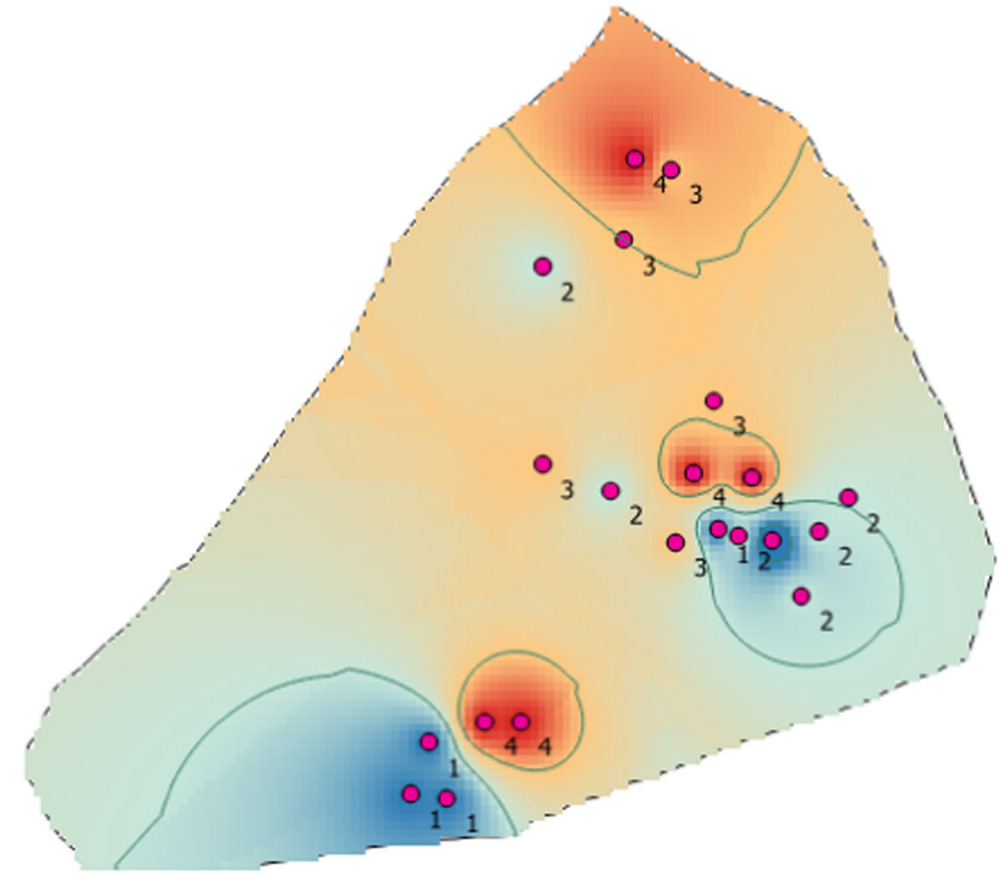

domestic waste, sewage sludge used for agricultural purposes, and organic matter (Barzegar et al. 2017; Sharma et al. 2016). PC5 has a high positive loading on $\mathrm{Fe}^{2+}$. The poor correlation between $\mathrm{Fe}^{2+}$ and $\mathrm{Mn}$ (0.07) implies that the two metals are not from the same source and therefore suggests that a significant proportion of $\mathrm{Fe}^{+}$did not emanate from the aquifer materials. It was earlier inferred that the high concentrations of $\mathrm{Fe}^{2+}$ in the water samples could have been as a result of the corrosion of conveyance pipes and pump materials by water of low $\mathrm{pH}$. Hence, this component most likely represents the influence of pumping and conveyance on water quality. PC6 has a high negative loading on temperature $(r=-0.91)$ and high positive loadings of 0.57 and 0.47 on $\mathrm{Ca}^{2+}$ and $\mathrm{F}^{-}$, respectively. Hence, PC6 indicates the contributions of the dissolution of paleosols and quartzite near the groundwater table (Chuah et al. 2016; Emenike et al. 2018; Xiao et al. 2015).

\section{Geospatial variation of water quality}

Figure 4 shows that groundwater in Abeokuta South exhibited a high degree of spatial variability. Most of the ions, such as $\mathrm{Cl}^{-}, \mathrm{Mg}^{2+}, \mathrm{SiO}_{2}, \mathrm{HCO}_{3}{ }^{-}, \mathrm{F}^{-}$, $\mathrm{Ca}^{2+}, \mathrm{SO}_{4}^{-}$, and $\mathrm{K}^{+}$, recorded the highest values in the southern part of the study area. The highest concentration of $\mathrm{Na}^{+}$occurred in the northern part while the highest concentrations of $\mathrm{Fe}^{2+}, \mathrm{CO}_{3}{ }^{-}$, and $\mathrm{HCO}_{3}{ }^{-}$occurred closer to the city center. In order to enhance the interpretation of these geospatial maps, cluster analysis was applied to the hydrochemical parameters obtained from all the sampling points (Fig. 5). The analysis yielded four hydrochemical clusters of the study area with characteristics shown in Table 5. The average concentrations of water quality parameters were compared with WHO guideline values for drinking water. Clusters 3 and 4 exhibited the worst violations of water quality standards with percent violation of 57.1 and $64.3 \%$, respectively. Both of these clusters had average TDS concentration greater than $1000 \mathrm{mg} / \mathrm{l}$, which renders them only useful for irrigation as per the classification of Davis and De Wiest (1966). Cluster 2 was found to possess the best hydrochemical quality followed by cluster 1 with percent violations of 13.3 and $26.7 \%$, respectively. Despite the relatively good groundwater quality of cluster 2, it was found that all but one of the groundwater samples from this cluster had $\mathrm{pH}$ values less than 6.5. The decreasing order of water quality was cluster $2>$ cluster $1>$ cluster $3>$ cluster 4. Based on the hierarchical CG, a composite geospatial map of the study area was produced. Some tap water gets contaminated at the source 


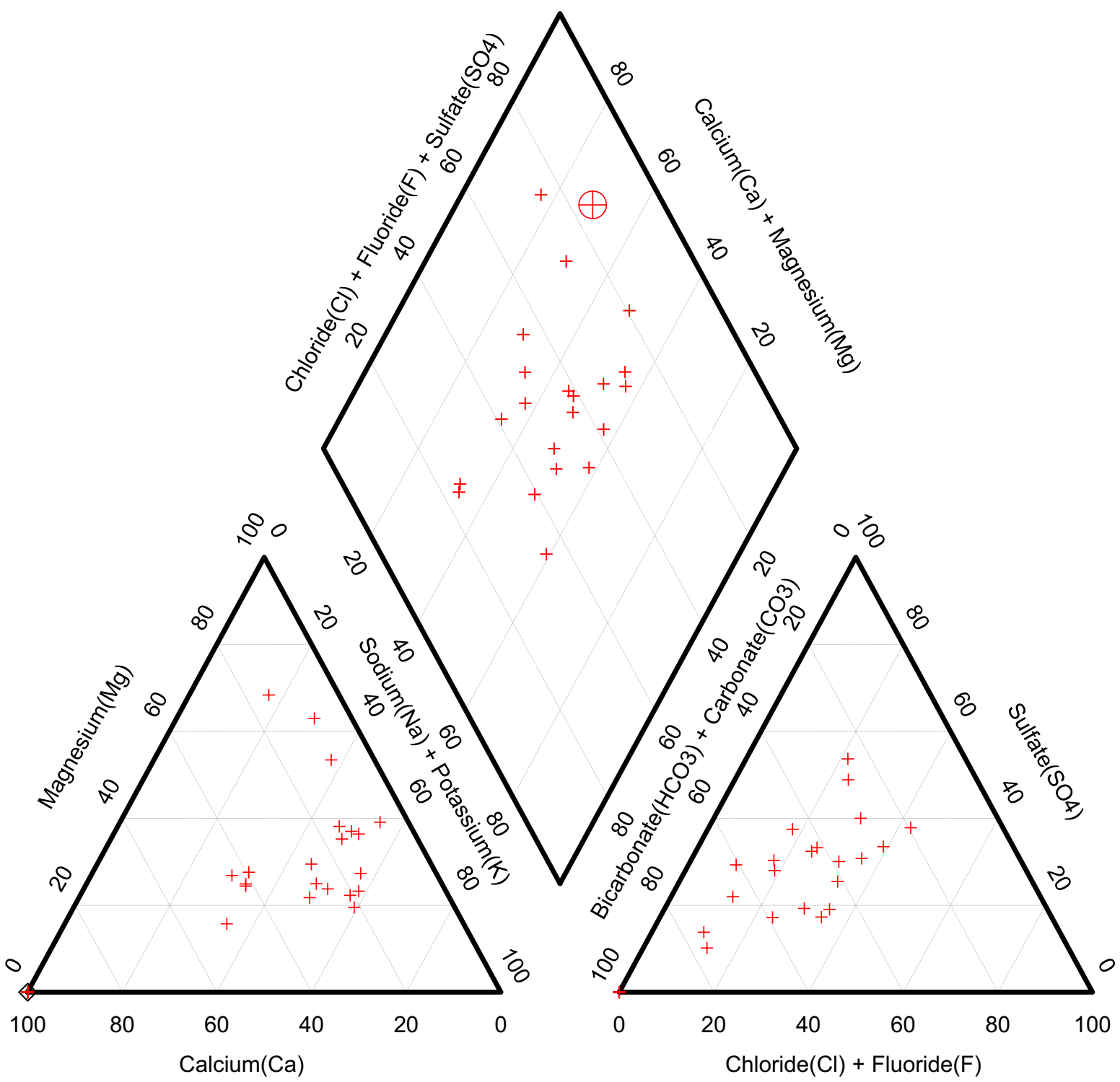

Fig. 7 Piper diagram showing the hydrological facies of the groundwater samples

and also after treatment unknowing to the consumers due to negligence to identify possible contamination points before being supplied publicly or privately (Tenebe et al. 2017). These points of contamination are mainly from indiscriminate discharge from anthropogenic, commercial, or industrial activities (Olusheyi 2017; Tenebe et al. 2018). With this in mind, the variability of water quality within the study area was largely associated with the distinct individual and cooperate activities engaged by inhabitants within the as reported in the literature (Table 6).
Figure 6 shows that the best groundwater quality exists in the eastern and southwestern areas of the study location, while worst groundwater quality exists at the city center. This again points to the significant influence of anthropogenic activities on groundwater quality. Urban areas are prone to elevated nutrient levels as a result of industrial, residential, and agricultural practices (Sarukkalige 2011). Industries contributing to water pollution in Abeokuta South includes sawmills, breweries, abattoirs, agricultural practices, automobile shops, and numerous illegal solid waste dumps in the municipality. 
Water quality assessment

The Piper-trilinear plot (Piper 1944) displays the classification of water samples from different lithological environment. It also represents the chemical character of the water samples using the dominant cation and anion to tell the differences and similarities of the groundwater samples. In this study, chemical data was plotted on a Piper diagram (Fig. 7), and the results revealed that $38 \%$ of the samples could be classified as $\mathrm{Na}-\mathrm{K}-\mathrm{HCO}_{3}$ type, $29 \%$ of the samples as $\mathrm{Na}-\mathrm{K}-\mathrm{Cl}-$ $\mathrm{SO}_{4}$ type, $24 \%$ of the samples as $\mathrm{Ca}-\mathrm{Mg}-\mathrm{HCO}_{3}$ type, and $9 \%$ as $\mathrm{Ca}-\mathrm{Mg}-\mathrm{Cl}-\mathrm{SO}_{4}$ type. The results also suggest the dominance of $\mathrm{Na}$ which could be as a result of weathering of rocks (Xiao et al. 2015). Furthermore, it could be said that multiple processes contribute to the composition of the hydrochemical facies as this can be from the mixed groundwater types. The Piper plot (Fig. 7) also revealed $\mathrm{Na}^{+}$and $\mathrm{K}^{+}$dominance in the cation composition, while $\mathrm{HCO}_{3}{ }^{2-}$ and $\mathrm{SO}_{4}{ }^{2-}$ dominate the anion composition in the groundwater samples.

\section{Conclusion}

This study reported the levels of groundwater quality parameters used for agricultural, domestic, and drinking purposes in Abeokuta, Nigeria. The results revealed that the water quality parameters showed wide spatial variations with $\mathrm{pH}$ and temperature having the least variability of 5.9 and 4.5 , respectively. Most of the water samples $(71 \%)$ fell within the slightly acidic range indicating dissolution of complex basement rocks. Violations of water standards were in order of $\mathrm{Na}>\mathrm{Mg}>$ $\mathrm{Fe}>\mathrm{EC}$, which suggests interaction with sodiumbearing rocks. The groundwater groupings can be ranked as $\mathrm{Ca}-\mathrm{Mg}-\mathrm{Cl}-\mathrm{SO}_{4}>\mathrm{Ca}-\mathrm{Mg}-\mathrm{HCO}_{3}>\mathrm{Na}-\mathrm{K}-\mathrm{Cl}-$ $\mathrm{SO}_{4}>\mathrm{Na}-\mathrm{K}-\mathrm{HCO}_{3}$ indicating mixed type. Mineral dissolution from soil and aquifer as well as anthropogenic activities, such as agriculture and waste management, were the major sources of hydrochemical variation in the study area. The very high concentration of TDS in the water samples were identified as a serious source of health concern. The findings of this research will be beneficial to water management authorities to understand the hydrochemistry of the groundwater potentials in the region for efficient and sustainable management.
Open Access This article is distributed under the terms of the Creative Commons Attribution 4.0 International License (http:// creativecommons.org/licenses/by/4.0/), which permits unrestricted use, distribution, and reproduction in any medium, provided you give appropriate credit to the original author(s) and the source, provide a link to the Creative Commons license, and indicate if changes were made.

\section{References}

Adekunle, A. A., Badejo, A. O., \& Oyerinde, A. O. (2013). Pollution studies on ground water contamination: water quality of Abeokuta, Ogun State, southwest Nigeria. Journal of Environment and Earth Science, 3(5), 161-166.

Aghazadeh, N., Chitsazan, M., \& Golestan, Y. (2016). Hydrochemistry and quality assessment of groundwater in the Ardabil area, Iran. Applied Water Science, 7(7), 35993616. https://doi.org/10.1007/s13201-016-0498-9.

Akoto, O., Gyamfi, O., Darko, G., \& Barnes, V. R. (2017). Changes in water quality in the Owabi water treatment plant in Ghana. Applied Water Science, 7(1), 175-186. https://doi. org/10.1007/s13201-014-0232-4.

Aly, A. A. (2015). Hydrochemical characteristics of Egypt western desert oases groundwater. Arabian Journal of Geosciences, 8(9), 7551-7564. https://doi.org/10.1007/s12517-014-1680-8.

Amori, A. A., Oduntan, O. O., Okeyode, I. C., \& Ojo, S. O. (2013). Heavy metal concentration of groundwater deposits in Odeda Region, Ogun State, Nigeria. Journal of Environmental Research and Management, 4(5), 253-259.

APHA. (2005). Standard methods for the examination of water \& wastewater (21st ed.). Washington D.C.: American Public Health Association https://books.google.co. $\mathrm{uk} /$ books/about/Standard Methods_for the Examination of.html?id=buTn1rmfSI4C\&redir_esc $=$ y. Accessed $2 \overline{7}$ December 2017.

Arulbalaji, P., \& Gurugnanam, B. (2017). Groundwater quality assessment using geospatial and statistical tools in Salem District, Tamil Nadu, India. Applied Water Science, 7(6), 2737-2751. https://doi.org/10.1007/s13201-016-0501-5.

Assubaie, F. N. (2015). Assessment of the levels of some heavy metals in water in Alahsa Oasis farms, Saudi Arabia, with analysis by atomic absorption spectrophotometry. Arabian Journal of Chemistry, 8(2), 240-245. https://doi.org/10.1016 /j.arabjc.2011.08.018.

Ayele, S., Raghuvanshi, T. K., \& Kala, P. M. (2014). Landscape ecology and water management. In: Landscape ecology and water management: proceedings of Igu Rohtak Conference (Vol. 2, pp. 15-32). Springer International Publishing. doi: https://doi.org/10.1007/978-4-431-54871-3

Barzegar, R., Asghari Moghaddam, A., \& Tziritis, E. (2017). Hydrogeochemical features of groundwater resources in Tabriz plain, northwest of Iran. Applied Water Science, 7, 3997-4011. https://doi.org/10.1007/s13201-017-0550-4.

Bora, M., \& Goswami, D. C. (2016). Water quality assessment in terms of water quality index (WQI): case study of the Kolong River, Assam, India. Applied Water Science, 7(6), 31253135. https://doi.org/10.1007/s13201-016-0451-y. 
Cao, Y., Tang, C., \& Song, X. (2014). Identifying the hydrochemical characteristics of rivers and groundwater by multivariate statistical analysis in the Sanjiang Plain, China. Applied Water Science, 6, 169-178. https://doi.org/10.1007 /s13201-014-0215-5.

Chandrasekar, N., Selvakumar, S., Srinivas, Y., John Wilson, J. S., Simon Peter, T., \& Magesh, N. S. (2014). Hydrogeochemical assessment of groundwater quality along the coastal aquifers of southern Tamil Nadu, India. Environmental Earth Sciences, 71(11), 4739-4750. https://doi.org/10.1007 /s12665-013-2864-3.

Chen, L., Gui, H., \& Yin, X. (2011). Monitoring of flow field based on stable isotope geochemical characteristics in deep groundwater. Environmental Monitoring and Assessment, 179(1-4), 487-498. https://doi.org/10.1007/s10661-0101751-6.

Chuah, C. J., Lye, H. R., Ziegler, A. D., Wood, S. H., Kongpun, C., \& Rajchagool, S. (2016). Fluoride: a naturally-occurring health hazard in drinking-water resources of Northern Thailand. Science of the Total Environment, 545-546, 266279. https://doi.org/10.1016/j.scitotenv.2015.12.069.

Das, S., \& Nag, S. K. (2017). Application of multivariate statistical analysis concepts for assessment of hydrogeochemistry of groundwater - a study in Suri I and II blocks of Birbhum District, West Bengal, India. Applied Water Science, 7(2), 873-888. https://doi.org/10.1007/s13201-015-0299-6.

Davis, S. N., \& De Wiest, R. J. M. (1966). Hydrogeology. Hoboken: Wiley.

Edjah, A. K. M., Akiti, T. T., Osae, S., Adotey, D., \& Glover, E. T. (2017). Hydrogeochemistry and isotope hydrology of surface water and groundwater systems in the Ellembelle district, Ghana, West Africa. Applied Water Science, 7(2), 609-623. https://doi.org/10.1007/s13201-015-0273-3.

El Alfy, M., Alharbi, T., \& Mansour, B. (2018). Integrating geochemical investigations and geospatial assessment to understand the evolutionary process of hydrochemistry and groundwater quality in arid areas. Environmental Monitoring and Assessment, 190(5), 277. https://doi. org/10.1007/s10661-018-6640-4.

Emenike, P. C., Omole, D. O., Ngene, B. U., \& Tenebe, I. T. (2016). Potentiality of agricultural adsorbent for the sequestering of metal ions from wastewater. Global Journal of Environmental Science and Management, 2(4), 411-442. https://doi.org/10.22034/gjesm.2016.02.04.010.

Emenike, C. P., Tenebe, I. T., Omole, D. O., Ngene, B. U., Oniemayin, B. I., Maxwell, O., \& Onoka, B. I. (2017a). Accessing safe drinking water in sub-Saharan Africa: Issues and challenges in south-west Nigeria. Sustainable Cities and Society, 30, 263-272. https://doi.org/10.1016/j. scs.2017.01.005.

Emenike, P. C., Tenebe, T. I., Omeje, M., \& Osinubi, D. S. (2017b). Health risk assessment of heavy metal variability in sachet water sold in Ado-Odo Ota, south-western Nigeria. Environmental Monitoring and Assessment, 189(9), 1-16. https://doi.org/10.1007/s10661-017-6180-3.

Emenike, C.P., Tenebe, I.T., Jarvis, P., (2018). Fluoride contamination in groundwater sources in Southwestern Nigeria: Assessment using multivariate statistical approach and human health risk. Ecotoxicology and Environmental Safety, 156, 391-402. https://doi.org/10.1016/j.ecoenv.2018.03.022.
Etteieb, S., Cherif, S., \& Tarhouni, J. (2015). Hydrochemical assessment of water quality for irrigation: a case study of the Medjerda River in Tunisia. Applied Water Science, 7, 112. https://doi.org/10.1007/s13201-015-0265-3.

Fijani, E., Moghaddam, A. A., Tsai, F. T. C., \& Tayfur, G. (2017). Analysis and assessment of hydrochemical characteristics of Maragheh-Bonab plain aquifer, northwest of Iran. Water Resources Management, 31(3), 765-780. https://doi. org/10.1007/s11269-016-1390-y.

Gao, H. W., Lin, J., Li, W. Y., Hu, Z. J., \& Zhang, Y. L. (2010). Formation of shaped barium sulfate-dye hybrids: waste dye utilization for eco-friendly treatment of wastewater. Environmental Science and Pollution Research, 17(1), 7883. https://doi.org/10.1007/s11356-009-0249-7.

Gbadebo, A. M. (2012). Groundwater fluoride and dental fluorosis in southwestern Nigeria. Environmental Geochemistry and Health, 34(5), 597-604. https://doi.org/10.1007/s10653-0129455-1.

Giridharan, L., Venugopal, T., \& Jayaprakash, M. (2008). Evaluation of the seasonal variation on the geochemical parameters and quality assessment of the groundwater in the proximity of River Cooum, Chennai, India. Environmental Monitoring and Assessment, 143(1-3), 161178. https://doi.org/10.1007/s10661-007-9965-y.

Giridharan, L., Venugopal, T., \& Jayaprakash, M. (2009). Assessment of water quality using chemometric tools: a case study of River Cooum, South India. Archives of Environmental Contamination and Toxicology, 56(4), 654669. https://doi.org/10.1007/s00244-009-9310-2.

Golchin, I., \& Moghaddam, M. A. (2016). Hydro-geochemical characteristics and groundwater quality assessment in Iranshahr plain aquifer, Iran. Environmental Earth Sciences, 75(4), 1-14. https://doi.org/10.1007/s12665-015-5077-0.

Islam, S. M. D.-U., Bhuiyan, M. A. H., Rume, T., \& Azam, G. (2017). Hydrogeochemical investigation of groundwater in shallow coastal aquifer of Khulna District, Bangladesh. Applied Water Science, 7, 1-18. https://doi.org/10.1007 /s13201-017-0533-5.

Junge, B., Alabi, T., Sonder, K., Marcus, S., Abaidoo, R., Chikoye, D., \& Stahr, K. (2010). Use of remote sensing and gis for improved natural resources management: case study from different agroecological zones of West Africa. International Journal of Remote Sensing, 31(23), 61156141. https://doi.org/10.1080/01431160903376415.

Karikari, A. Y., \& Ansa-Asare, O. D. (2006). Physico-chemical and microbial water quality assessment of Densu River of Ghana. West Africa Journal of Applied Ecology, 10(1), 1-12. https://doi.org/10.4314/wajae.v10i1.45701.

Karkra, R., Kumar, P., Bansod, B. K. S., Bagchi, S., Sharma, P., \& Krishna, C. R. (2016). Classification of heavy metal ions present in multi-frequency multi-electrode potable water data using evolutionary algorithm. Applied Water Science, 7, 111. https://doi.org/10.1007/s13201-016-0514-0.

Khound, N. J., \& Bhattacharyya, K. G. (2016). Multivariate statistical evaluation of heavy metals in the surface water sources of Jia Bharali river basin, North Brahmaputra plain, India. Applied Water Science, 7(5), 2577-2586. https://doi. org/10.1007/s13201-016-0453-9.

Li, P., Qian, H., Wu, J., Zhang, Y., \& Zhang, H. (2013). Major ion chemistry of shallow groundwater in the Dongsheng 
coalfield, Ordos Basin, China. Mine Water and the Environment, 32(3), 195-206. https://doi.org/10.1007 /s10230-013-0234-8.

Maiti, S., Erram, V. C., Gupta, G., Tiwari, R. K., Kulkarni, U. D., \& Sangpal, R. R. (2013). Assessment of groundwater quality: a fusion of geochemical and geophysical information via Bayesian neural networks. Environmental Monitoring and Assessment, 185(4), 3445-3465. https://doi.org/10.1007 /s10661-012-2802-y.

Nag, S. K., \& Das, S. (2017). Assessment of groundwater quality from Bankura I and II Blocks, Bankura District, West Bengal, India. Applied Water Science, 7(6), 2787-2802. https://doi. org/10.1007/s13201-017-0530-8.

National Population Commission. (2010). Population distribution by sex, state, LGA \& senatorial district. 2006 population and housing cencus (Vol. III). http://www.population.gov. ng/images/Vol03TableDSxLGAPopbySDistrict-PDF.pdf.

Nazeer, S., Hashmi, M. Z., \& Malik, R. N. (2014). Heavy metals distribution, risk assessment and water quality characterization by water quality index of the River Soan, Pakistan. Ecological Indicators, 43, 262-270. https://doi.org/10.1016 /j.ecolind.2014.03.010.

Nematollahi, M. J., Ebrahimi, P., Razmara, M., \& Ghasemi, A. (2016). Hydrogeochemical investigations and groundwater quality assessment of Torbat-Zaveh plain, Khorasan Razavi, Iran. Environmental Monitoring and Assessment, 188(1), 121. https://doi.org/10.1007/s10661-015-4968-6.

Odjegba, E., Idowu, O., Ikenweiwe, N., Martins, O., \& Sadeeq, A. (2015). Public perception of potable water supply in Abeokuta. Journal of Applied Sciences and Environmental Management, 19(1), 5-9.

Ogbiye, A. S., Emenike, C. P., Tenebe, I. T., \& Kafi, C. . (2018). Human health risk assessment data of trace elements concentration in tap water-Abeokuta South, Nigeria. Data in Brief, 18, 1416-1426. https://doi.org/10.1016/j.dib.2018.04.041.

Ojekunle, O. Z., Ojekunle, O. V., Adeyemi, A. A., Taiwo, A. G., Sangowusi, O. R., Taiwo, A. M., \& Adekitan, A. A. (2016). Evaluation of surface water quality indices and ecological risk assessment for heavy metals in scrap yard neighbourhood. Springerplus, 5, 560. https://doi. org/10.1186/s40064-016-2158-9.

Oke, S. A., \& Tijani, M. N. (2012). Impact of chemical weathering on groundwater chemistry of Abeokuta area. Elixir Pollution, $46,8498-8503$.

Olusheyi, O. Z. (2017). Groundwater quality attrition by mechanic workshop activities in Abeokuta Metropolis, Ogun State, Nigeria. Merit Research Journal of Environmental Science and Toxicology, 5(2), 18-24.

Panno, S. V., Hackley, K. C., Hwang, H. H., Greenberg, S. E., Krapac, I. G., Landsberger, S., \& O'Kelly, D. J. (2006). Characterization and identification of $\mathrm{Na}-\mathrm{Cl}$ sources in ground water. Ground Water, 44(2), 176-187. https://doi. org/10.1111/j.1745-6584.2005.00127.x.

Pazand, K., Hezarkhani, A., Ghanbari, Y., \& Aghavali, N. (2012). Groundwater geochemistry in the Meshkinshahr basin of Ardabil province in Iran. Environmental Earth Sciences, 65(3), 871-879. https://doi.org/10.1007/s12665-011-1131-8.

Pinto, D., Shrestha, S., Babel, M. S., \& Ninsawat, S. (2017). Delineation of groundwater potential zones in the Comoro watershed, Timor Leste using GIS, remote sensing and analytic hierarchy process (AHP) technique. Applied Water
Science, 7(1), 503-519. https://doi.org/10.1007/s13201015-0270-6.

Piper, A. M. (1944). A graphic procedure in the geochemical interpretation of water-analyses. Eos, Transactions American Geophysical Union, 25(6), 914-928. https://doi. org/10.1029/TR025i006p00914.

Ramya, P., Babu, A. J., Reddy, E. T., Rao, L. V., \& District, Y. S. R. K. (2015). A study on the estimation of hardness in ground water samples by edta tritrimetric method of Veterinary Public Health and Epidemiology College of Veterinary Science, Proddatur. International Journal of Recent Scientific Research, 6, 4505-4507.

Rao, P. V. N., Rao, S. A., \& Rao, N. S. (2015). Geochemical evolution of groundwater in the Western Delta region of River Godavari, Andhra Pradesh, India. Applied Water Science, 7(2), 813-822. https://doi.org/10.1007/s13201015-0294-y.

Rasool, A., Xiao, T., Farooqi, A., Shafeeque, M., Masood, S., Ali, S., Fahad, S., \& Nasim, W. (2016). Arsenic and heavy metal contaminations in the tube well water of Punjab, Pakistan and risk assessment: a case study. Ecological Engineering, 95, 90-100. https://doi.org/10.1016/j.ecoleng.2016.06.034.

Romshoo, S. A., Dar, R. A., Murtaza, K. O., Rashid, I., \& Dar, F. A. (2017). Hydrochemical characterization and pollution assessment of groundwater in Jammu Siwaliks, India. Environmental Monitoring and Assessment, 189(3), 122. https://doi.org/10.1007/s10661-017-5860-3.

Salari, A., Zakaria, M., Nielsen, C. C., \& Boyce, M. S. (2014). Quantifying tropical wetlands using field surveys, spatial statistics and remote sensing. Wetlands, 34(3), 565-574. https://doi.org/10.1007/s13157-014-0524-3.

Sarukkalige, P. R. (2011). Assessment of spatial variation of groundwater quality and its relationship with land use in Perth metropolitan. Journal of Water Resource and Protection, 03(05), 311-317. https://doi.org/10.4236 /jwarp.2011.35039.

Selvakumar, S., Ramkumar, K., Chandrasekar, N., Magesh, N. S., \& Kaliraj, S. (2014). Groundwater quality and its suitability for drinking and irrigational use in the Southern Tiruchirappalli District, Tamil Nadu, India. Applied Water Science, 7, 411-420. https://doi.org/10.1007/s13201-0140256-9.

Selvakumar, S., Ramkumar, K., Chandrasekar, N., Magesh, N. S., \& Kaliraj, S. (2017). Groundwater quality and its suitability for drinking and irrigational use in the Southern Tiruchirappalli District, Tamil Nadu, India. Applied Water Science, 7(1), 411-420. https://doi.org/10.1007/s13201014-0256-9.

Sharma, D. A., Rishi, M. S., \& Tirumalesh, K. (2016). Evaluation of groundwater quality and suitability for irrigation and drinking purposes in southwest Punjab, India using hydrochemical approach. Applied Water Science, 7(6), 3137-3150. https://doi.org/10.1007/s13201-016-0456-6.

Sreedhar, A. N. Y., Mohammad, A. T., \& Sayadi, H. (2016). Water quality analysis of the Rapur area, Andhra Pradesh, South India using multivariate techniques. Applied Water Science, 7(6), 2767-2777. https://doi.org/10.1007/s13201-016-0504-2.

Taiwo, A. M. (2012). Source identification and apportionment of pollution sources to groundwater quality in major cities in southwest, Nigeria. Geofizika, 29(2), 157-174. 
Taiwo, A. M., Arowolo, T. A., Adekunle, I. M., \& Adetunji, M. T. (2013). Evaluating the environmental impacts of poultry farming on stream water quality: a study from Abeokuta, Nigeria. Environmental Quality Management, 49, 79-93. https://doi.org/10.1002/tqem.

Tenebe, I. T., Ogbiye, A., Omole, D. O., \& Emenike, P. C. (2016). Estimation of longitudinal dispersion coefficient: a review. Cogent Engineering, 3(1), 1-16. https://doi.org/10.1080 /23311916.2016.1216244.

Tenebe, I. T., Ogbiye, A. S., Omole, D. O., \& Emenike, P. C. (2017). Modelling and sensitivity analysis of varying roughness effect on dispersion coefficient: a laboratory study. Desalination and Water Treatment, 21298, 1-7. https://doi. org/10.5004/dwt.2017.21298.

Tenebe, I. T., Emenike, C. P., \& Daniel Chukwuka, C. (2018). Prevalence of heavy metals and computation of its associated risk in surface water consumed in Ado-Odo Ota, south-west Nigeria. Human and Ecological Risk Assessment: an International Journal, 0(0), 1-23. doi:https://doi. org/10.1080/10807039.2018.1454824.

Tiwari, A. K., \& Singh, A. K. (2014). Hydrogeochemical investigation and groundwater quality assessment of Pratapgarh District, Uttar Pradesh. Journal Geological Society of India, 83, 329-343.

Ufoegbune, G. ., Lamidi, K. ., Awomeso, J. ., Eruola, A. ., \& Idowu, O. (2009). Hydro-geological characteristics and groundwater quality assessment in some selected communities of Abeokuta, Southwest Nigeria. Journal of Environmental Chemistry and Ecotoxicology, 1(1), 010-022.

Vázquez-Suñé, E., Sánchez-Vila, X., \& Carrera, J. (2005). Introductory review of specific factors influencing urban groundwater, an emerging branch of hydrogeology, with reference to Barcelona, Spain. Hydrogeology Journal, 13(3), 522-533. https://doi.org/10.1007 /s10040-004-0360-2.

Wang, S. (2013). Groundwater quality and its suitability for drinking and agricultural use in the Yanqi Basin of Xinjiang Province, Northwest China. Environmental Monitoring and Assessment, 185(9), 7469-7484. https://doi.org/10.1007 /s10661-013-3113-7.

WHO. (2017). The cost of a polluted environment: 1.7 million child deaths a year, says WHO. Geneva: WHO. World Health Organization http://www.who.int/mediacentre/news/releases/2017 /pollution-child-death/en/. Accessed Nov 182017.

WHO, \& UNICEF. (2014). Progress on sanitation and drinkingwater-2014 update. Monitoring programme for water supply and sanitation. doi:978 9241507240.

Xiao, J., Jin, Z., \& Zhang, F. (2015). Geochemical controls on fluoride concentrations in natural waters from the middle Loess Plateau, China. Journal of Geochemical Exploration, 159, 252-261. https://doi.org/10.1016/j.gexplo.2015.09.018.

Yidana, S. M. (2010). Groundwater classification using multivariate statistical methods: southern Ghana. Journal of African Earth Sciences, 57(5), 455-469. https://doi.org/10.1016/j. jafrearsci.2009.12.002.

Zaidi, F. K., Mogren, S., Mukhopadhyay, M., \& Ibrahim, E. (2016). Evaluation of groundwater chemistry and its impact on drinking and irrigation water quality in the eastern part of the Central Arabian graben and trough system, Saudi Arabia. Journal of African Earth Sciences, 120, 208-219. https://doi. org/10.1016/j.jafrearsci.2016.05.012. 